Received $\quad 31.05 .2017$

Reviewed 07.12 .2017

Accepted 20.12.2017

A - study design

B - data collection

C - statistical analysis

D - data interpretation

$\mathbf{E}$ - manuscript preparation

F - literature search

\section{Analysis of future climate scenarios and their impact on agriculture in eastern Arkansas, United States}

\author{
John W. MAGUGU ${ }^{\text {ACEF } \bowtie}$, Song FENG ${ }^{\text {ADEF }}$, Qiuqiong HUANG ${ }^{\text {BE }}$, \\ Yongjun ZHANG ${ }^{\mathrm{C}}$, Grant H. WEST ${ }^{\mathrm{B}}$
}

University of Arkansas, 615 N Court St, 72701 Carlisle, USA; e-mail: jwmagugu@uark.edu, songfeng@uark.edu, qqhuang@uark.edu, Yongjun.Zhangcn@gmail.com, gwest@uark.edu

For citation: Magugu J.W., Feng S., Huang Q., Zhang Y., West G.H. 2018. Analysis of future climate scenarios and their impact on agriculture in eastern Arkansas. Journal of Water and Land Development. No. 37 p. 97-112. DOI: 10.2478/jwld-2018-0029.

\begin{abstract}
Impact of climate change on crop growth is dynamic and difficult to quantify due to heterogeneity of the associated effects and their interactions within the Earth system. The main objective of this study is to establish how future climate change might affect agriculture, through an assessment of temperature and precipitation driven parameters. These include percentage number of rainy days with extreme precipitation, percentage of extreme precipitation relative to wet days, first fall frost days, last spring frost days, growing degree days, growing season length and the total precipitation. Results show modest increase in total precipitation with a slight increase in extreme precipitation, representing up to $2.2 \%$ increase by 2060 under representative concentration pathway (RCP 8.5) scenario. There would be late first fall frost days, early last spring frost days and increased growing season length by up to 2 weeks in 2060 . The growing degree days are projected to increase under all scenarios for all crops, with cotton showing the largest increase of up to $37 \%$ relative to the baseline period.
\end{abstract}

Key words: agriculture, climate change, climate scenarios, precipitation, temperature

\section{INTRODUCTION}

Climate is the major factor that dominates the production environment in the agricultural sector. Climate change has been manifested through an increase in global average surface temperatures by approximately $0.7^{\circ} \mathrm{C}$ in the last $20^{\text {th }}$ century [MELILLO et al. (eds.) 2014]. Most of this change has been prevalent from 1970s to the present day [FENG, Hu 2004; MOONEN et al. 2002]. Even in the most optimistic scenario where greenhouse gases were held constant, the Earth's surface would still continue to warm by about $0.6^{\circ} \mathrm{C}$ over the $21^{\text {st }}$ century relative to year 2000 [STOCKER et al. 2013a]. Due to the elevated greenhouse gases (GHGs), future atmospheres will be warmer and capable of holding more moisture [DRAKE et al. 1997; MORISON, GIFFORD 1984]. In fact, the atmosphere can retain approximately 7\% more water vapour for every extra degree of air temperature [STOCKER et al. 2013a]. Therefore, more intense precipitation is anticipated in a future warmer climate [ALEXANDER et al. 2006; HATFIELD et al. 2011; ZHANG et al. 2007b].

Future precipitation projections are less certain than projections for temperature due to local physiographic and atmospheric effects [INGRAM et al. 2013; PINGALE et al. 2015]. Increases in precipitation can still be undone through heat stress projected to reduce crop productivity coupled with drought effects [KARL, MELILLO 2009]. In addition, temperature effects will lead to increased transpiration from plants and evaporation from soils and water reserves. Hence, there will be reduced water availability due to increased evapo- 
rative losses from rising temperatures alone [INGRAM et al. 2013].

Most studies have claimed that climate change has altered agricultural environment and affected crop production through factors such as shifts in growing season, changes in planting dates or extreme weather events [FEng, Hu 2004; MoONEN et al. 2002]. The general consensus is that climate change will lower yields for the most important crops: corn, soybean, and wheat [BLANC et al. 2013]. Impacts on water resources include changes in the timing of water availability due to changes in snow and rainfall. Additionally, shifts in water demands caused by increased temperatures together with changes in surface water availability and groundwater storage will have negative impacts [MOONEN et al. 2002; ROSEGRANT et al. 2009]. Therefore, alterations in temperature and precipitation may affect the demand for irrigation water both by quantity and timing as well as irrigation water supply [ELLIOTT et al. 2014; SCHEWE et al. 2014; SCHLENKER et al. 2007].

In this study, we will focus on Arkansas, US, because its agriculture relies heavily on irrigation. Arkansas is a major agricultural producer and the largest producer of rice in the nation, with other major crops including soybean, corn, wheat and cotton [NICKERSON et al. 2011]. Most of these rice farms are way inland, far from the delta where water table is higher. This is the key factor that necessitates supplementary irrigation by farmers; making Arkansas the fourth largest user of groundwater in the nation [HOLLAND 2007; SCHAIBLE, AILlERY 2012]. The climate of Arkansas is humid sub-tropical, with average temperatures of about $15.8^{\circ} \mathrm{C}$ [FENG et al. 2014]. The major rainy season in Arkansas occurs from March to May and then from October to December according to Offices of the Arkansas State Climatologist, 2014.

Climate change may affect Arkansas' agriculture both directly through its effect on crop growth and indirectly through its effect on irrigation water supply. The growth of rice is highly sensitive to temperatures in the phonological stages. Temperatures below $20^{\circ} \mathrm{C}$ or above $35^{\circ} \mathrm{C}$ will cause floral or spikelet sterility reducing yields [SATAKE, HAYASE 1970; WALTHALL et al. 2012]. It is also anticipated that soybean will have increased photosynthesis and respiration for higher temperatures [BERNACCHI et al. 2006; LEAKEY et al. 2009; WALTHALL et al. 2012]. Soybean yields are projected to drop by approximately $2.4 \%$ in the $21^{\text {st }}$ century under climate change [HATFIELD et al. 2011; WALTHALL et al. 2012]. In addition, research projects a $1.3 \%$ drop in soybean yields for every $1.0^{\circ} \mathrm{C}$ rise in temperature [LOBELL, FIELD 2007].

A $0.8^{\circ} \mathrm{C}$ rise in temperature over the next 30 years would cause a 2 to $3 \%$ fall in corn yield excluding effects of soil and moisture deficits. These are just conservative estimates and do not consider interactions of temperature and water availability. A further $8.3 \%$ drop in corn yields would be anticipated for every $1.0^{\circ} \mathrm{C}$ rise in temperature [LOBELL, FIELD
2007]. For wheat, warmer temperature will increase development, shorten crop cycle and duration of filling [PORTER, GAWITH 1999].

Cotton is also very sensitive to high temperatures during phonological stages, especially during the reproductive development and anthesis. Flowering is the most temperature sensitive of all the phenological stages [MITRA 2001; SNIDER et al. 2013]. Temperatures outside threshold limits can reduce carbohydrate formation from photosynthesis, boll retention and seed development [LOKA, OOSTERHUIS 2010; WALTHALL et al. 2012]. In addition to crop growth, climate change will affect Arkansas' irrigated agriculture through its impact on water resources. The major source of irrigation water in Arkansas is groundwater, which is affected by the variability in annual precipitation due to rainwater recharge [CZARNECKI, SCHRADER 2013].

The study will focus on five major crops: rice, corn, soybean, wheat and cotton. Climate scenarios considered will include representative concentration pathways (RCP) 4.5, 6.0 and 8.5 for 2030 and 2060 . This study will shed light on the projected changes on agro-meteorological indices and their impact on Arkansas' agriculture. These include the distribution of precipitation, first and last frost days, growing season length and growing degree days shifts under various scenarios of climate change in 2030 and 2060.

\section{DATA AND METHODS}

\section{STUDY REGION}

The study sites encompass three eight-digit hydrological unit code watersheds (L'anguille, Big, and the Lower White), within farming region of the Arkansas Delta where the Mississippi alluvial aquifer is most depleted. The study area consists of 2,725 grid cells averaging 243 ha each (Fig. 1). It lies within latitudes 35.99 and $33.95^{\circ} \mathrm{N}$ and longitudes 90.29 and $91.34^{\circ} \mathrm{W}$. The study area is less differentiated geographically; most of it lies in the Mississippi River valley in eastern Arkansas, a predominantly flat alluvial plane.

\section{DATA}

The daily temperature (minimum, maximum and mean) and precipitation on 2725 grid points in the study regions during the baseline (1981-2010) were obtained from National Center for Environmental Prediction/National Center for Atmospheric Research (NCEP-NCAR) reanalysis data derived from the 50year global meteorological forcing datasets, developed by SHEFFIELD et al. [2006]. This is a nearsurface meteorological daily dataset at $\left(1^{\circ} \times 1^{\circ}\right)$ resolution blended with reanalysis data for driving land surface models including other terrestrial modelling systems in time and space. The data was sourced from 11 weather stations from each county for the entire study area for baseline scenario (1980-2010). 


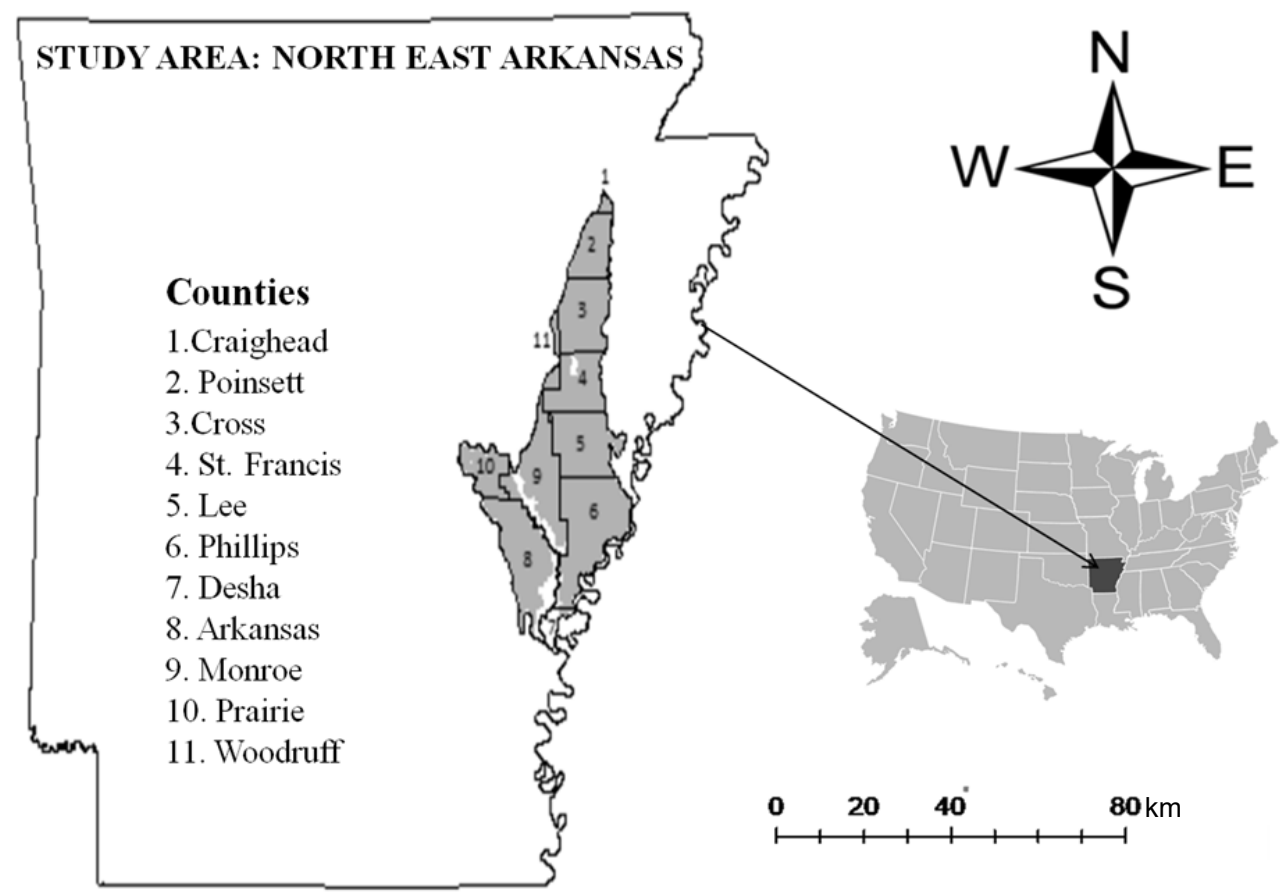

Fig. 1. Study area in North-East of Arkansas; source: own elaboration

The daily temperature and precipitation during 2030 and 2060 under three greenhouse gas concentration trajectories (RCP 4.5, RCP 6.0 and RCP 8.5) were used in this study. These scenarios were chosen because they represent mild, moderate and severe trajectories for climate change [STOCKER et al. 2013b]. The future climate data were derived from the ensemble of forty global climate models. The daily data for the three future scenarios were obtained through a perturbation process with Decision Support System for Agro Technology transfer (DSSAT) perturb tool [Mereu et al. 2012].

It should be noted that the perturbed data for 2030 were delegates of the 30 year period centered at 2030 (2016-2045). It is not the actual time series for 2016 to 2045 . The same is true for the period 2060, which is a statistical representation of years between 2046 and 2075. The climate data were generated for all 2,725 grid cells in the study site. All the variables for the 30 year period for each scenario in each grid cell were averaged to represent the probable climate scenario for 2030 and 2060.

\section{DATA ANALYSIS}

\section{Precipitation indicators}

Three precipitation related measures were constructed from the daily precipitation data; annual total precipitation, number of days with extreme precipitation and extreme precipitation. Extreme precipitation is defined as any precipitation above 1 inch (25.4 $\mathrm{mm}$ ) in a single day for the study area based on upper 10 percentiles in the precipitation distribution [KUNKEL et al. 1999].

\section{Temperature based indicators}

The growth of a plant is nonlinear in the whole range of temperature; linear relationship is only observed between crop specific lower and upper threshold temperatures [SCHLENKER et al. 2005]. Below the lower threshold temperature or above the upper threshold temperature, crop growth stops, resulting in no additional growing degree days (GDDs), a measure of heat accumulation [HASSAN et al. 2007]. For instance, yield increases for corn were observed up to $29^{\circ} \mathrm{C}$, but temperatures above the threshold was found to be harmful [SCHLENKER, ROBERTS 2009]. The calculation of GDD in the unit of degree days is given by the following equation:

$$
G D D=\sum_{P_{b}}^{P_{e}} \frac{\left(T_{\max }+T_{\min }\right)}{2}-T_{b}
$$

Where: $T_{\max }$ and $T_{\min }=$ the daily maximum and minimum surface air temperature; $P_{b}$ and $P_{e}=$ the beginning and ending dates of the growth season [FENG, HU 2004]; $T_{b}=$ threshold temperature; $T_{b}$ are set for different crops (rice, corn, soybean, wheat and cotton).

Beyond the threshold temperatures, crop growth is suppressed and so this is factored when calculating thermal time for individual crops because they do not accumulate additional GDDs [FENG, HU 2004; MCMASTER, WILHELM 1997]. The threshold temperatures were set to be $10^{\circ} \mathrm{C}$ and $30^{\circ} \mathrm{C}$ for rice and soybean; and $10^{\circ} \mathrm{C}$ and $29^{\circ} \mathrm{C}$ for corn [FENG, Hu 2004; SARMA et al. 2008]. Wheat had a base temperature of $15.5^{\circ} \mathrm{C}$ and an upper threshold temperature of $35^{\circ} \mathrm{C}$ [PATHAK et al. 2003]. For cotton the threshold temperatures were $15.6^{\circ} \mathrm{C}$ and $35^{\circ} \mathrm{C}$ respectively [Howell et al. 2004; PATHAK et al. 2003; SNOWDEN 
et al. 2013]. Since different crops grow during different times of the year, the planting and harvesting dates were obtained from University of Arkansas Division of Agriculture Cooperative Extension Services. The crop specific $P_{b s}$ and $P_{e s}$ are shown in Table 1.

Table 1. Planting and harvesting dates for respective crops

\begin{tabular}{|l|l|l|}
\hline \multicolumn{1}{|c|}{ Crop } & \multicolumn{1}{|c|}{ Planting date $\left(P_{b}\right)$} & \multicolumn{1}{c|}{ Maturity date $\left(P_{e}\right)$} \\
\hline Rice & $1^{\text {st }}$ May & $14^{\text {th }}$ September \\
\hline Soybean & $1^{\text {st }}$ June & $16^{\text {th }}$ October \\
\hline Corn & $1^{\text {st }}$ April & $1^{\text {st }}$ September \\
\hline Wheat & $1^{\text {st }}$ November & $15^{\text {th }}$ June following year \\
\hline Cotton & $1^{\text {st }}$ May & $6^{\text {th }}$ October \\
\hline
\end{tabular}

Source: NASS, USDA [1997].

Growing season length was a temperature defined variable. The length of growing season is defined as the number of days between the last frost day in spring and the first frost day in autumn [MOONEN et al. 2002]. Alternatively, growing season length is the period between the date of the last spring freeze and first autumn freeze [LINDERHOLM 2006].

\section{Analysis}

After calculating the agro-meteorological indicators for specific grid cells, within respective time series of baseline, 2030 and 2060, the results were averaged to depict the climate of each scenario. Closely related grid cell values were aggregated to obtain spatial representation of the agro-meteorological indicators for the study area. The model results were linked to coordinates for each grid cell to create a geodatabase and contour maps generated by ESRI ArcGIS Desktop [ESRI 2000]. The contour ranges remained consistent within each variable across model runs to allow for simple visual interpretation.

\section{RESULTS AND DISCUSSION}

\section{TRENDS IN PRECIPITATION}

The annual total precipitation for the baseline period is shown in Figure 2a. It depicts a slightly decreasing trend during 1981-2010. The inter-annual variations of the annual total precipitation during the
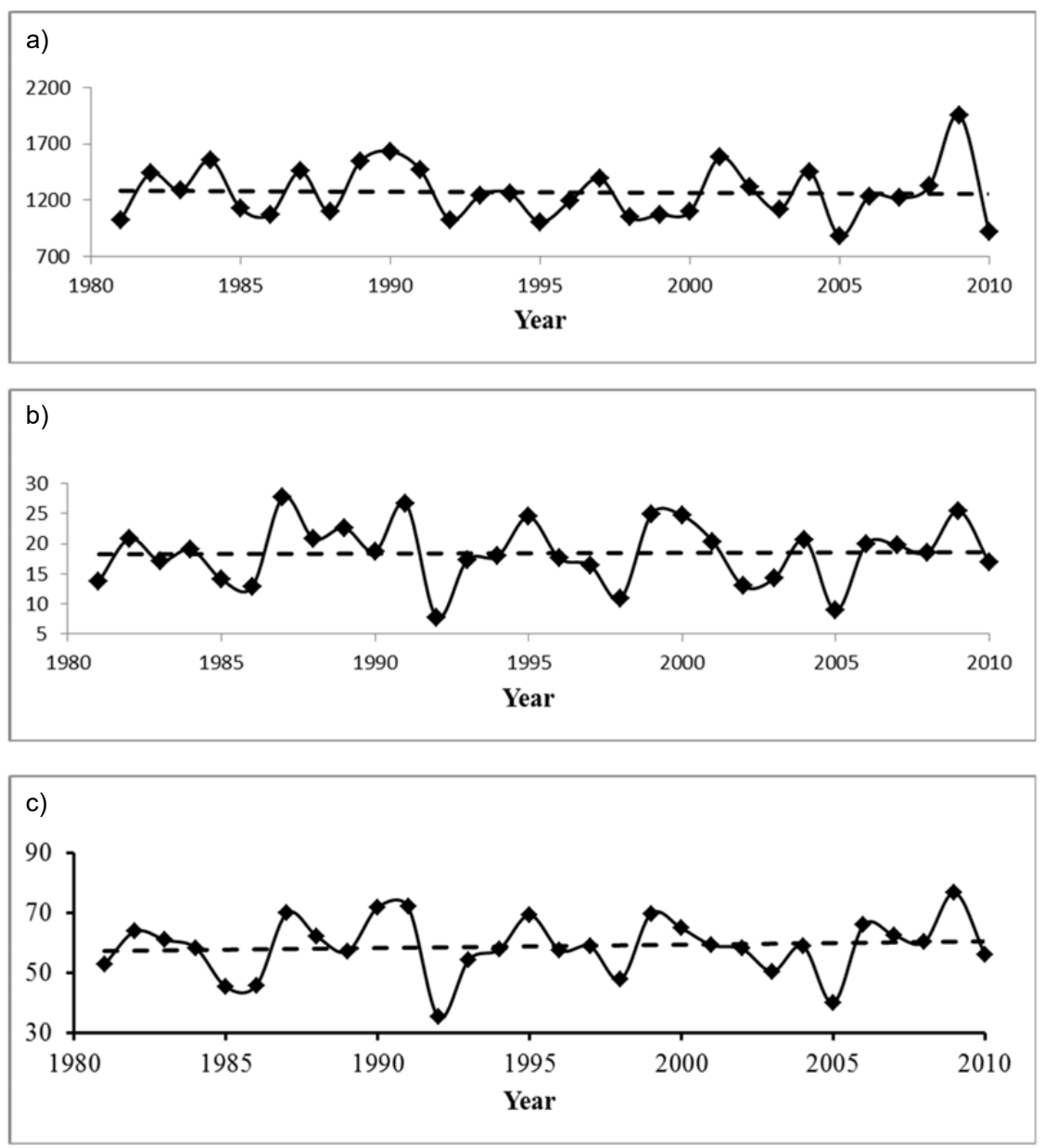

Fig. 2. Time trend of baseline period (1981-2010): a) total precipitation in $\mathrm{mm} \cdot \mathrm{y}^{-1}$,

b) percent of rainy days with extreme precipitation, c) percent of extreme precipitation relative to total precipitation; source: own study 
a)

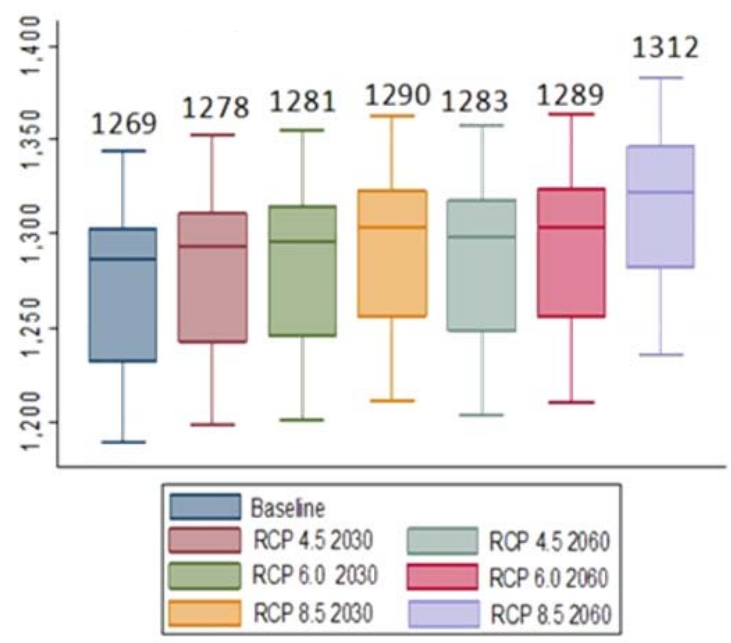

b)

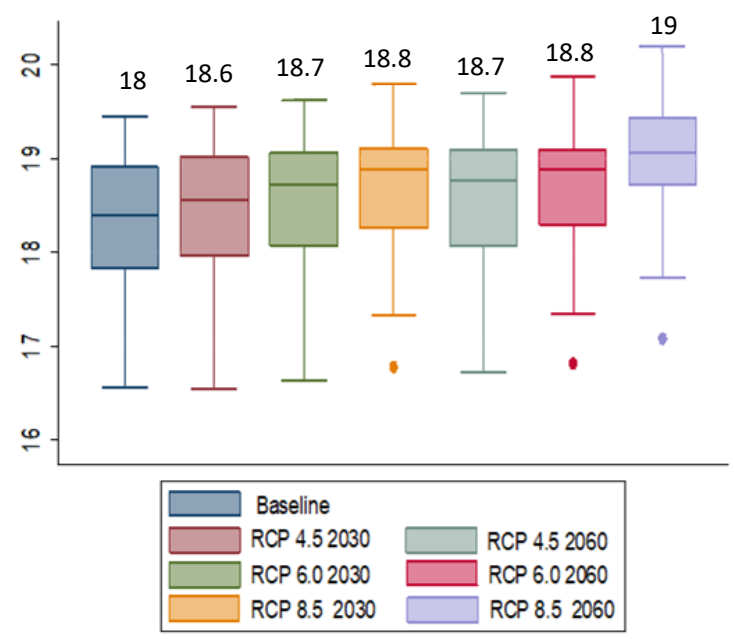

c) $\%$ of extreme precipitation relative to total precipitation

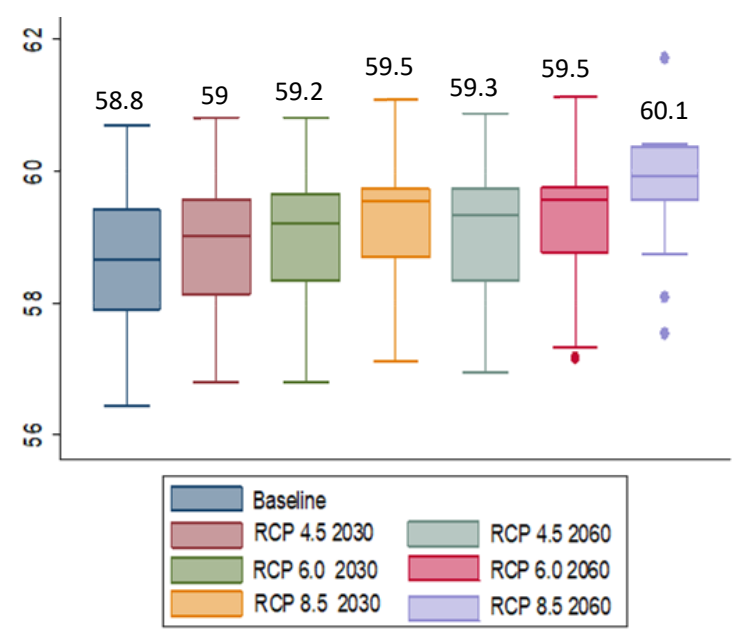

Fig. 3. Future scenarios under climate change and mean values: a) total precipitation, b) percent of rainy days with extreme precipitation, c) percent of extreme precipitation relative to total precipitation; $\mathrm{RCP}=$ representative concentration pathway; source: own study period 2000-2010 is stronger than in the two earlier decades, suggesting an increase in precipitation variability. However, there is a marginally increasing trend of rainy days with extreme precipitation over the same period (Fig. 2b). As a result, the percentage of extreme precipitation relative to the total precipitation is slightly increasing during the baseline period (Fig. 2c).

The total precipitation in 2030 under different Representative Concentration Pathway (RCP) scenarios are quite similar by spread, range and skewness. The median values increase steadily with higher scenarios of climate change or RCP $(4.5,6.0$ and 8.5) relative to baseline (Fig. 3a). The number of rainy days with extreme precipitation indicates little changes between baseline and RCP 4.5 and 6.0; albeit the datasets are more skewed to the left. Compared to other scenarios, the RCP 8.5 is slightly different with smaller spread and symmetric skewness. The median values increase marginally under higher scenarios (Fig. 3b). For percentage of extreme precipitation relative to total precipitation, there is no major difference between baseline and the 2030, although RCP 8.5 has a smaller spread and range. Median values of the scenarios increase with respect to higher RCP projections (Fig. 3c).

The median values of total precipitation show steady increase for higher RCP scenarios in 2060 (Fig $3 a)$. The number of rainy days with extreme precipitation follows a similar trend, except that RCP 4.5 has a larger spread and a bigger range (Fig 3b). For percent of extreme precipitation relative to total precipitation, the RCP 6.0 has a smaller spread while RCP 8.5 is more skewed to the right with a few outliers (Fig 3c).

Generally, there is a slight increase in total precipitation (Fig. 3a), number of rainy days with extreme precipitation (Fig. 3b) and percentage of extreme precipitation relative to total precipitation (Fig. $3 \mathrm{c}$ ) under all future scenarios. Relative to the baseline, the RCP 8.5 projected an average increase of $42 \mathrm{~mm}$ in precipitation totals which is approximately $3.2 \%$ change relative to baseline period (Fig. 3a). On the other hand, there is slight rise in the percent of rainy days with extreme precipitation which is approximately 5\% for RCP 8.5 (Fig. 3b). Furthermore, extreme precipitation is exhibiting a slight increasing trend for future scenarios representing a $2.2 \%$ rise from baseline period under RCP 8.5 in 2060 (Fig. 3c).

On average the southern region of the study area receives more precipitation than the north. Projections suggest greater increase in total precipitation in the northern parts of the study region in 2030 (Fig. 4b, c, d). The number of rainy days with extreme precipitation is more expressed in the north for the baseline period but 2030 scenarios project an increase of those days in the southern parts (Fig. 5b, c, d). Similarly, percentage of extreme precipitation is more pronounced on the north of the study area (Fig. 6a), with 2030 scenarios increases being more prominent on the south side albeit marginally (Fig. 6b, c, d). 
a)

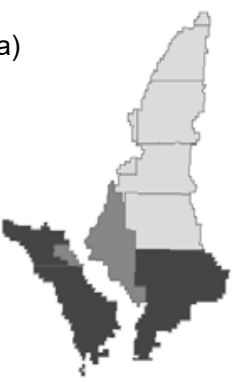

Total precipitation Baseline ( $\mathrm{mm}$ ) Avg_Basell

$\square 1226-1258$

1258 - 1290

1290 - 1321

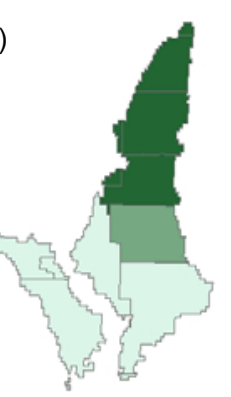

\% change under RCP 4.52060 Avg_Low206

$\square .93-1.09$
$1.09-1.24$

$1.09-1.24$ b)

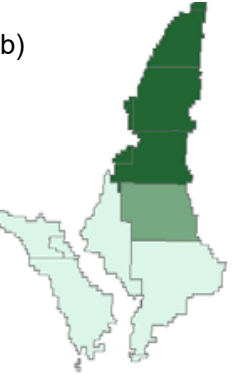

\% change under RCP 4.52030 Avg_Low203

口 $052-065$

$0.52-0.65$
$0.65-0.78$

$0.70 \cdot 0.90$ c)

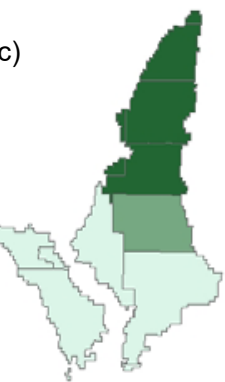

\% change under RCP 6.02030 Avg_Mid203

$0.69-0.86$
$0.86-1.03$

$1.03-1.21$ d)

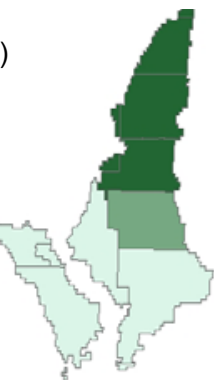

$\%$ change under RCP 8.52030 Avg_High20

$1.10-1.50$

$1.50-1.82$

$1.82 \cdot 2.14$
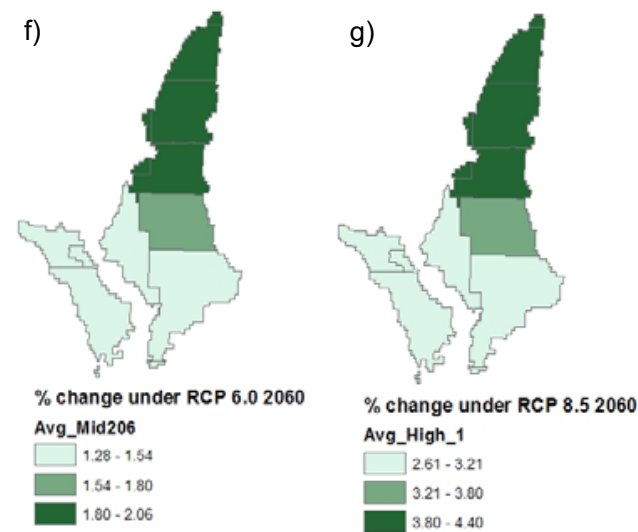

Fig. 4. Total precipitation in baseline period and spatial percentual change of total precipitation under scenarios of climate change; $\mathrm{RCP}$ = representative concentration pathway; source: own study
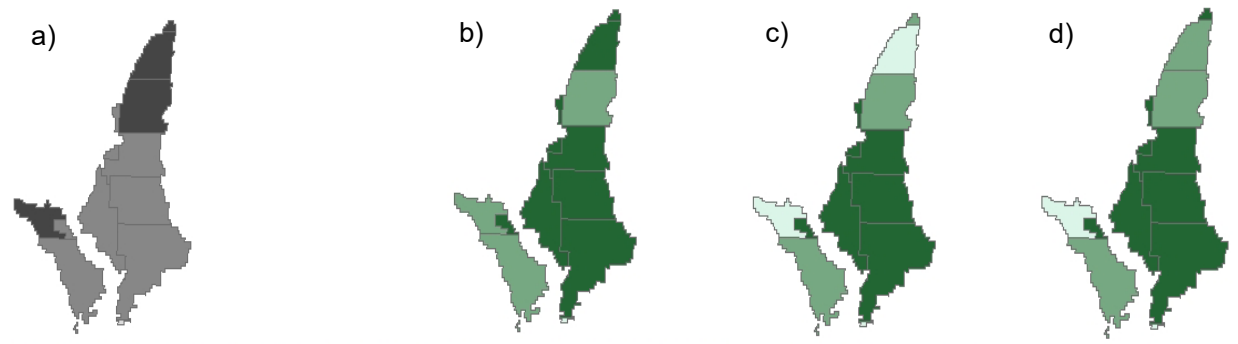

$\%$ rainy days with extreme precipitation Baseline Change under RCP 4.5 2030 Avg_Baseli

Change under RCP 4.5 2030 Change under RCP 6.0 2030

Change under RCP 8.52030

$16.6-17.5$
$\square$
$17.5-18.5$

Avg_Low203

$\square-0.13-0.26$

$0.26-0.65$

$0.65-1.03$

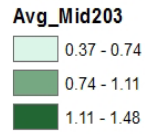

Avg_High20

$\begin{array}{r}\square \\ \square\end{array} 09-1.48$

$1.48-1.97$

$1.11-1.48$

$1.97-2.46$

e)

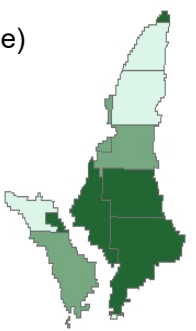

Change under RCP 4.52060

Avg_Low206

$\square 0.80-1.10$

$1.10-1.41$

$1.41-1.72$ f)

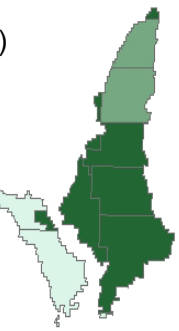

Change under RCP 6.02060 Avg_Mid206

$\square .99-1.53$

$1.53-2.07$

$2.07-2.60$

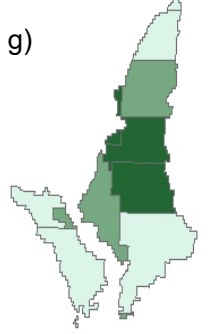

Change under RCP 8.52060

Avg_High_1

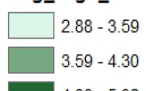

Fig. 5. Percentage of rainy days with extreme precipitation in baseline period and spatial change under scenarios of climate change; $\mathrm{RCP}$ = representative concentration pathway; source: own study 

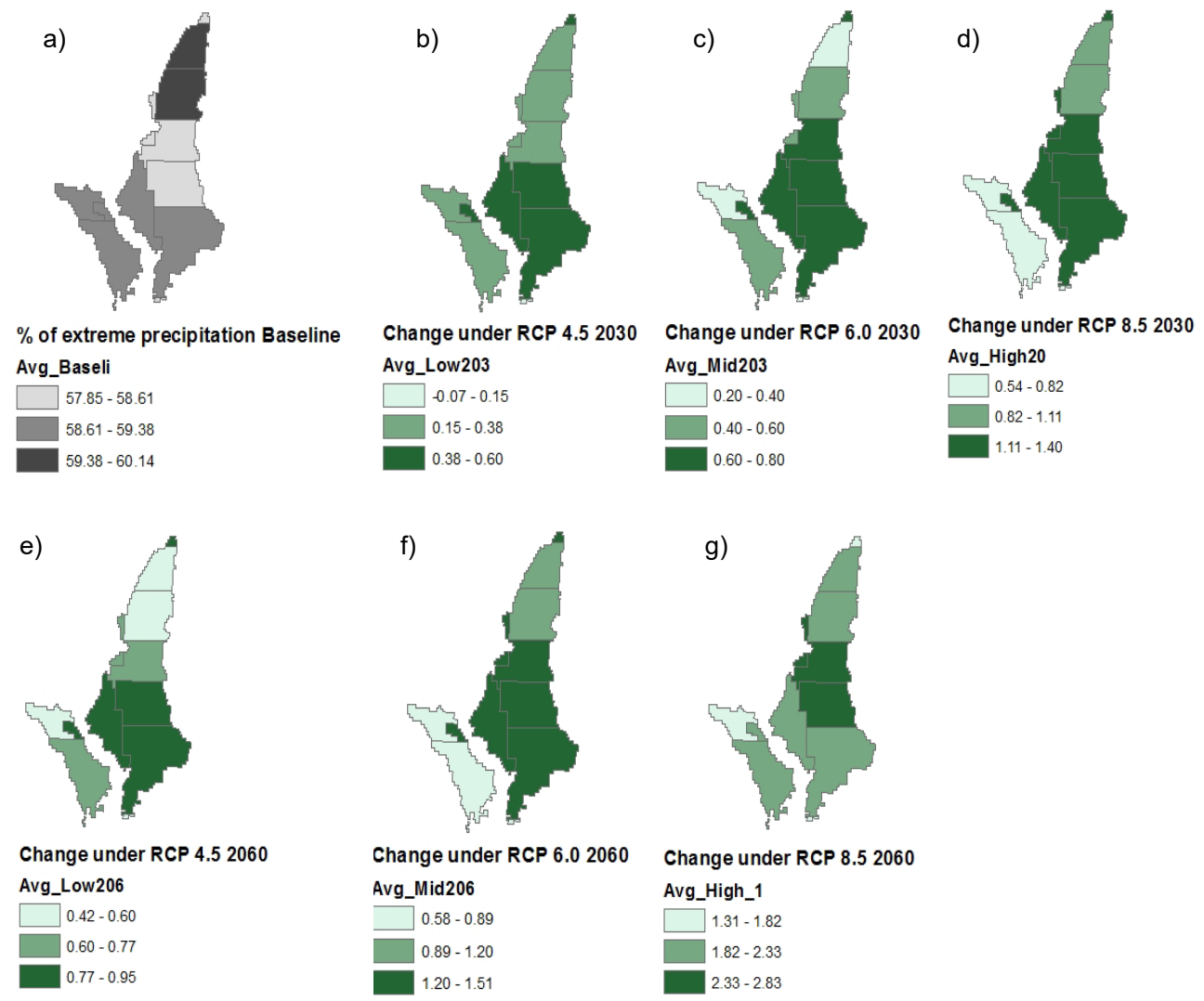

Fig. 6. Percent of extreme precipitation in baseline period and spatial change under scenarios of climate change; $\mathrm{RCP}=$ representative concentration pathway; source: own study

Under 2060 scenarios, increasing trend persists for total precipitation (Fig. 4e, f, g). The number of rainy days with extreme precipitation relative to baseline shows a steady increase for both RCP 4.5 and 6.0 with a shift towards the central study area witnessed for RCP 8.5 in the greatest positive change (Fig. 5g). The percentage of extreme precipitation increases marginally under RCP 4.5 and 6.0 south of the study area (Fig. 6e, f) but RCP 8.5 presents a shift to the center for the highest increases revealed (Fig. 6g).

These results reveal that, total precipitation will increase marginally, the number of days with extreme precipitation will not change much but the percentage of extreme precipitation relative to total precipitation would increase substantially, suggesting more intense rainfall in the future, i.e., "it will pour instead of rain".

\section{GROWING DEGREE DAYS}

Growth events of crop such as flowering and maturity depend on the accumulation of specific quantities of heat [MILLER et al. 2001]. For all crops studied, the growing degree days have been increasing during the last 30 years (Fig. 7). The growing degree days are projected to increase for all crops under all RCP scenarios. The highest increase is projected for RCP 8.5 scenario during 2030 and 2060 (Fig. 8).

The data is uniformly spread around the $25^{\text {th }}$ and $75^{\text {th }}$ quartile for RCP scenarios of 2030 and baseline for all the crops studied (Fig. 8). The ranges are quite identical with symmetrical skewness. However, there is significant increase in GDDs for all the crops (rice, corn, soybean, wheat and cotton), especially for higher GHGs emission scenarios.

Based on the scenario (Fig. 8), it is very likely that there will be at least a $9.0 \%$ average rise in GDDs for rice and corn in 2030 under RCP 8.5. Soybean GDD will rise by $7.8 \%$, wheat by $14.0 \%$ and cotton by $18.0 \%$ under RCP 8.5 in 2030 . For 2060 , the RCP 8.5 scenario leads to a $19.0 \%$ rise in GDDs of rice and corn with soybean GDD increasing by $16.0 \%$. Wheat and cotton are the biggest gainers at $30.0 \%$ and $37.0 \%$ respectively.

The southern part of the study area has more growing degree days on average than northern parts in the baseline period (Fig. 9). The patterns are similar for all other crops (not shown). The northern portion of the study area would witness the greatest change in GDDs. For rice, corn, soybean, wheat and cotton, there is a steady rise in GDDs for 2030 projections. These changes are more manifested in the northern region of the study area although with a small margin.

The 2060 scenario changes are quite consistent with 2030, except with a larger magnitude. Rice, corn and soybean GDDs are quite low for RCP 6.0 and RCP 8.5. However, wheat and cotton GDDs reveal highest percentage spatial change under RCP 8.5. Results show that the southern farmers will be the greatest beneficiaries of increases in GDDs for all crops under scenarios of climate change in 2030 and 2060. 

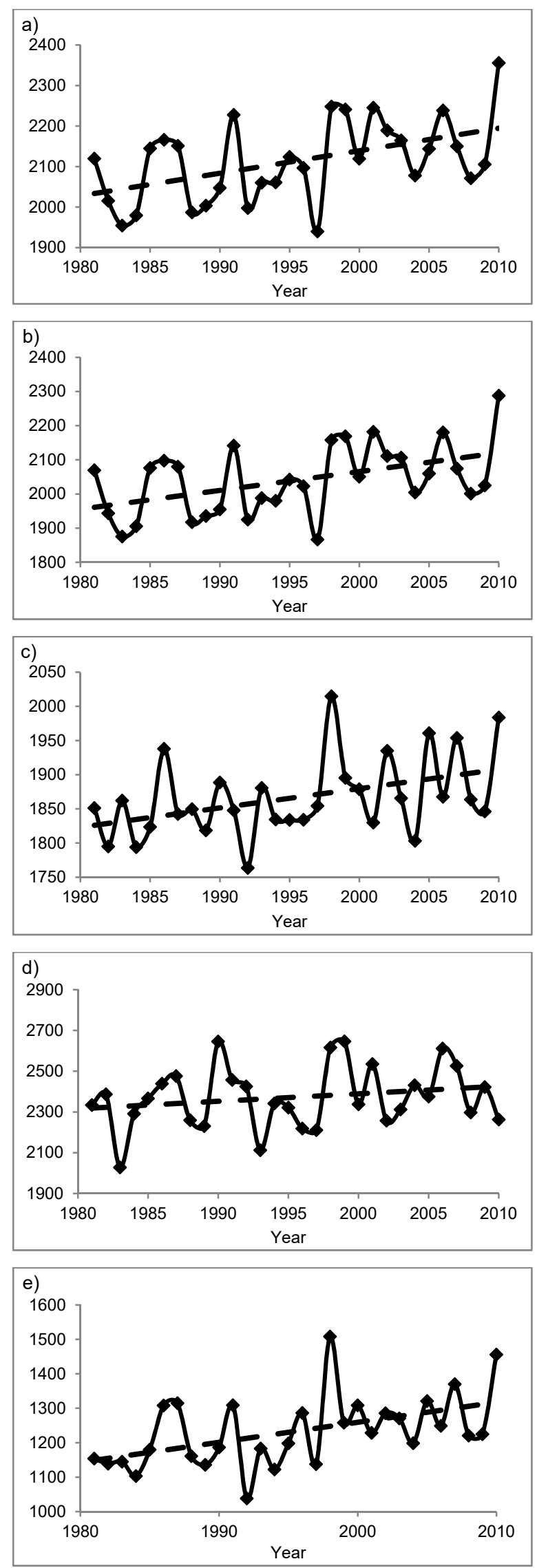

Fig. 7. Trend analysis for growing degree days (GDD) in baseline period: a) rice, b) corn, c) soybean, d) wheat, e) cotton; RCP = representative concentration pathway; source: own study a)

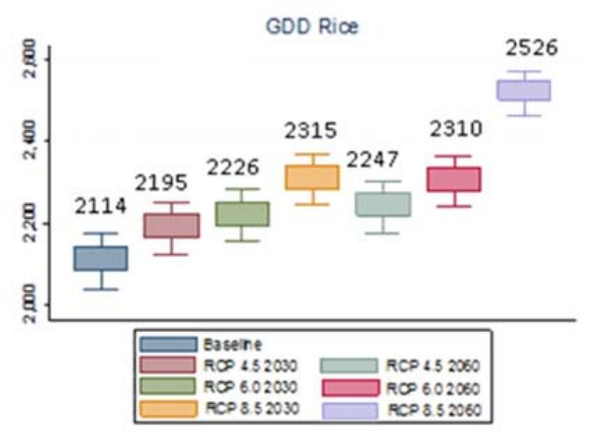

b)

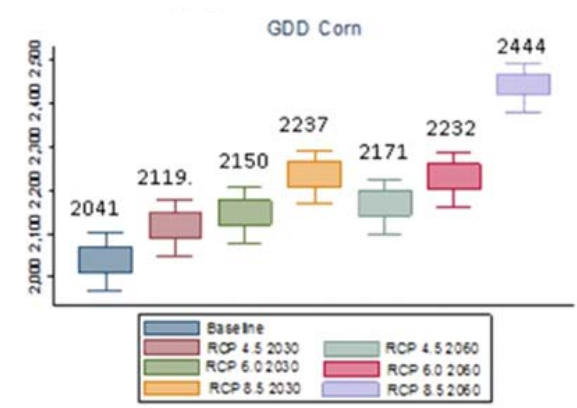

c)

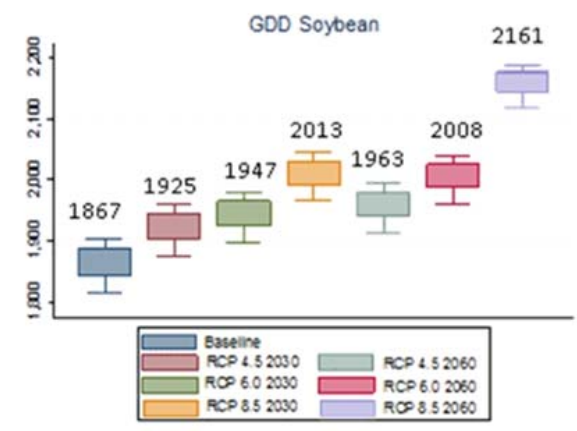

d)

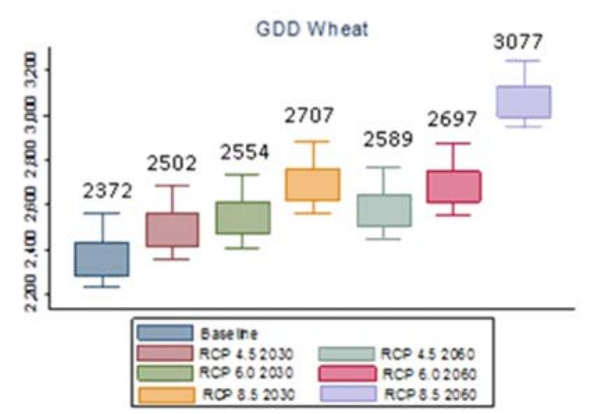

e)

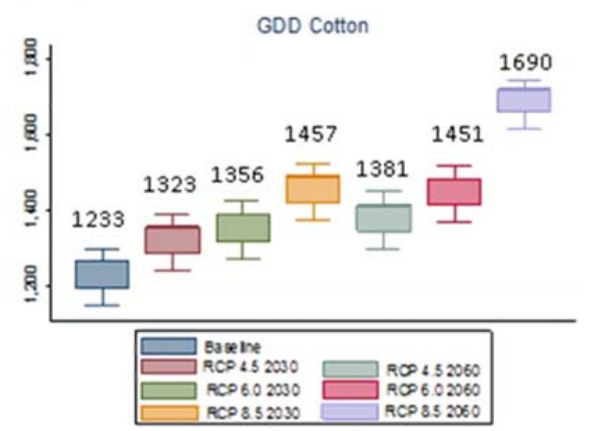

Fig. 8. Future scenarios under climate change and mean values for growing degree days (GDD): a) rice, b) corn, c) soybean, d) wheat and e) cotton; $\mathrm{RCP}=$ representative concentration pathway; source: own study 


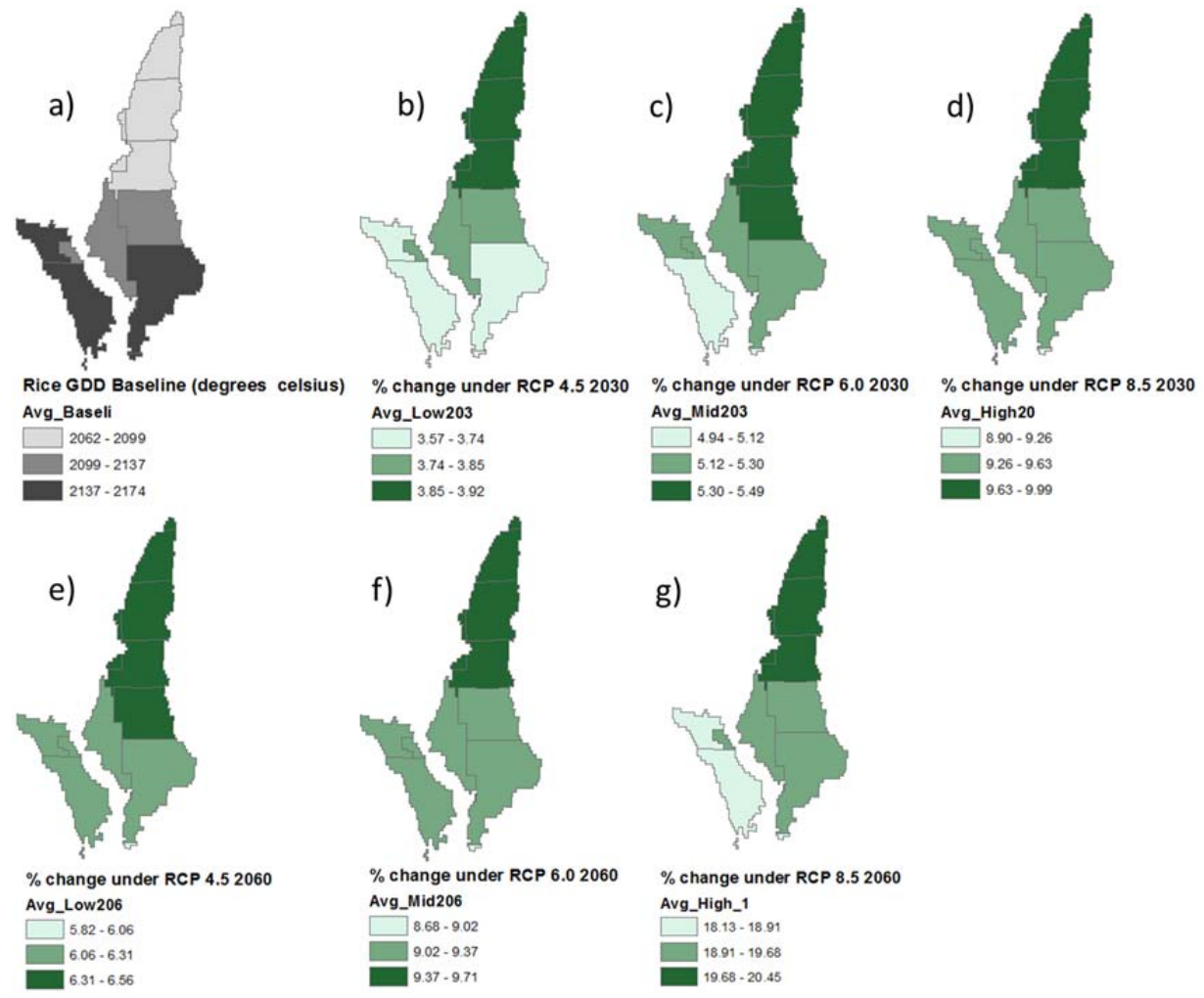

Fig. 9. Rice growing degree days (GDD) in baseline period and spatial change under scenarios of climate change; $\mathrm{RCP}=$ representative concentration pathway; source: own study
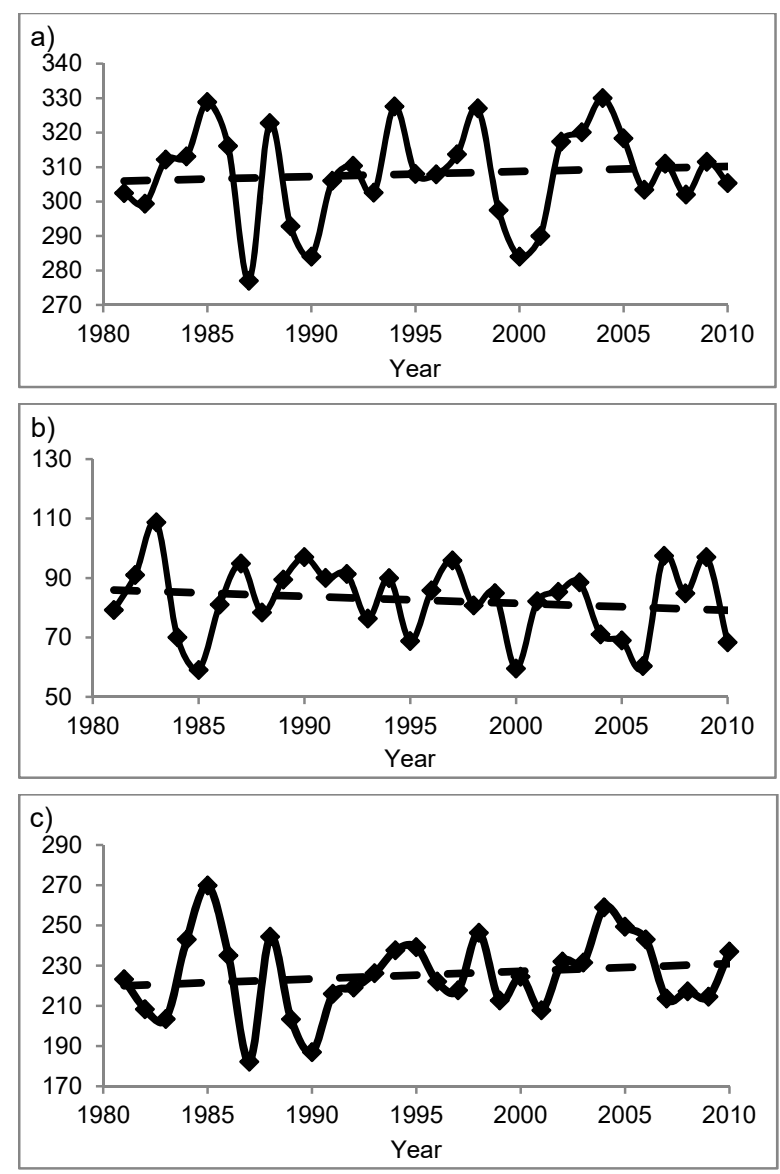

Fig 10. Time trend of baseline period (1981-2010): a) first fall frost day, b) last spring frost day, c) growing season length; source: own study

\section{FROST DAYS AND GROWING SEASON LENGTH}

For the last 30 years (1981-2010), the first fall frost day has been on the $308^{\text {th }}$ day on average (Fig. 10a) with the last spring frost day coming on the $76^{\text {th }}$ day of the following year (Fig. 10b). The frost risk period is thus within 133 days and the average growing season length is 225 days. The temporal variations of the first fall frost day and last spring frost day are both shown in Figure 10. On average, the first fall frost day has been fluctuating but with a tendency of coming late in the baseline period (Fig. 10a), while the last spring frost day exhibits a tendency of early arrival (Fig. 10b). These results are quite consistent with similar studies by FENG et al. [2004] and those by MOONEN et al. [2002], who identified increases in frost free days and lengthening of growing season in different parts of USA and Italy, respectively.

For 2030, baseline period has the smallest range; with the data being closely spread for first fall frost days. RCP (4.5 and 6.0) are a little skewed to the right but RCP 6.0 spread is smaller than the rest. RCP 8.5 has a bigger range and larger mean value. For 2060, RCP 4.5 data is less skewed with bigger spread but RCP 6.0 has the highest range. Median values for RCP scenarios also increase under higher RCP scenarios (Fig. 11a). Last spring frost days in 2030 show a general decreasing mean under RCP 4.5, 6.0 and 8.5 (Fig. 11b). RCP 8.5 has the largest range although it is skewed to the left. For 2060, RCP 6.0 has the largest range with RCP 8.5 having the largest inter-quartile range. 

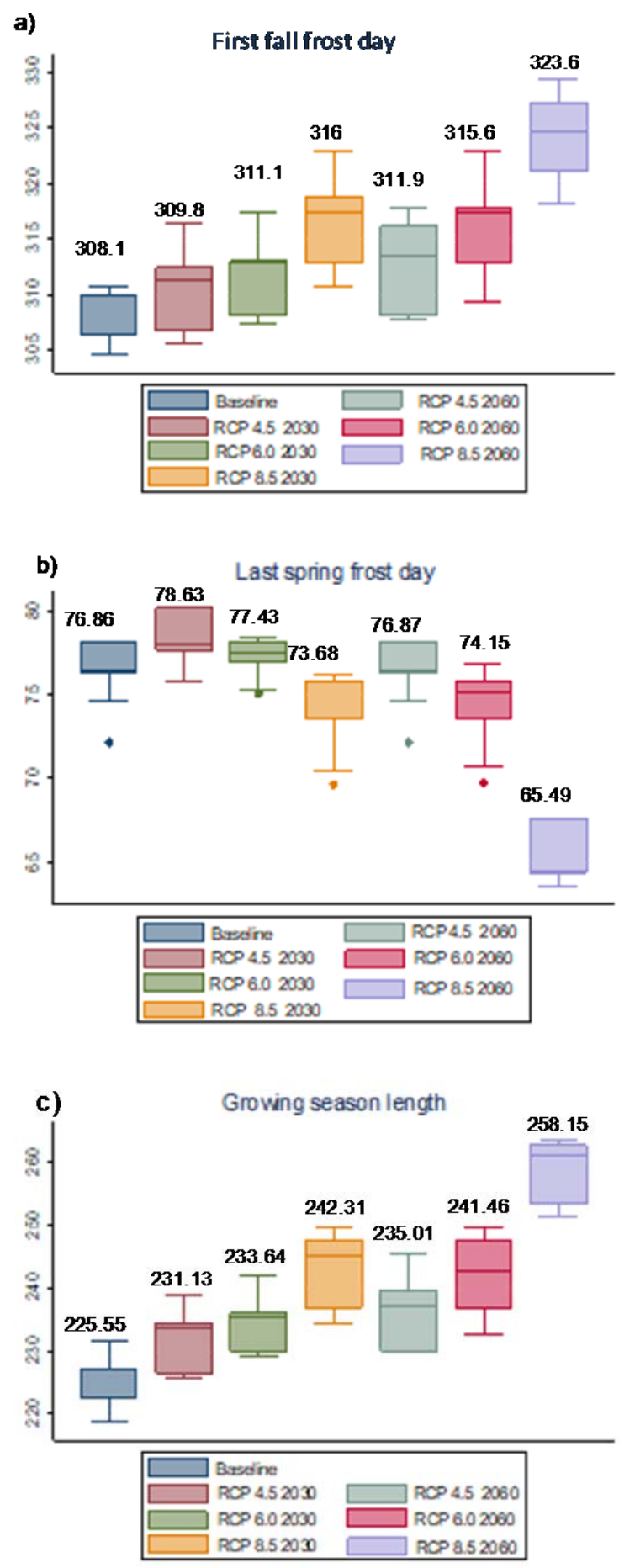

Fig. 11. Future scenarios under climate change and mean values; a) first fall frost day, b) last spring frost day,

c) growing season length; $\mathrm{RCP}=$ representative concentration pathway; source: own study

The last spring frost day exhibits a decreasing trend. The last spring frost day is projected to be 11 days earlier than the baseline period by 2060 under RCP 8.5 (Fig. 11b). The opposite trend is however exhibited for the first fall frost day, which will lead to delayed arrival of the first fall frost day. The greatest increases in the first fall frost days are under RCP 8.5 scenario during 2030 and 2060, each by 8 and 15 days relative to baseline period (Fig. 11a).
The first fall frost day is coming late in the southern parts of the study area for baseline period (Fig. 12a). Projections reveal a lengthening frost free period for the entire study area with more positive change to the south (Fig 12b, c, d). The south side witnesses earlier last spring frost days on average than the northern parts (Fig. 13a). For 2030, RCP 4.5 reveals marginal positive changes in the south side with most changes being north of the study area (Fig. 13b). There is a drop on the last spring frost days for RCP 6.0, with RCP 8.5 showing even a larger drop and eventual negative percentage change relative to baseline period (Fig. 13d).

First fall frost days are marginally increasing from north to south in 2060 (Fig. 12e, f, g). Ironically, there is no change in the appearance of last frost period for RCP 4.5 in 2060 (Fig. 13e). This means that, RCP 4.5 for 2060 will be similar to the current baseline conditions. RCP 6.0 and 8.5 both reveal a drop in the last spring frost days (Fig. 13f, g). On average, the last frost day will appear earlier on the southern part of the study area. Farmers in those areas will be the greatest beneficiaries of delayed frost period.

Frost is a major risk during growing seasons, so these results indicate a potential decrease in frost risks. This also means insurance premiums for frost risk would go down, which will in turn reduce fixed costs for farmers in Arkansas. Ideally, farmers in Arkansas should be able to plant longer season cultivars in addition to having a greater variety of other crops and sowing early. Our results are consistent with general results of model simulations of the recent past, which reveal a decrease in number of frost days in US with rise in greenhouse gases [GRIGGS, NoGUER 2002; MoOnEN et al. 2002]. Therefore, fewer frost days are projected to increase the growing season length [EASTERLING 2002].

Over the last 30 years, the growing season has shown a slight increase, probably due to changes in frost days (Fig. 10c). Results reveal that growing season length is increasing under all scenarios of climate change for 2030 and 2060 (Fig. 11c). It is imperative to note that by 2030, the growing season is projected to increase by 10 days on average; while for 2060 there would be an increase of about 19 days (Fig. 11c). Delayed frost in autumn and early start of growing season in the spring have been responsible for projected increase in growing season length, caused by the projected rise in average temperatures under all scenarios of climate change for 2030 and 2060.

For 2030 (Fig 11c), baseline shows symmetric distribution while RCP 4.5 and 6.0 are more skewed to the right. RCP 8.5 has the highest range and spread. Mean values show a steady increase with higher RCP scenarios. However, for 2060, RCP 4.5 has a smaller spread but RCP 6.0 is more symmetric with a larger range. All the RCP scenarios of growing season length reveal a tendency for longer seasons with higher RCP scenarios of climate change. 

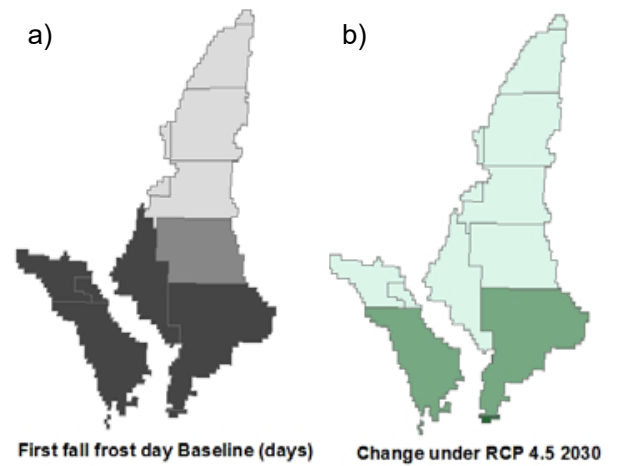

c)

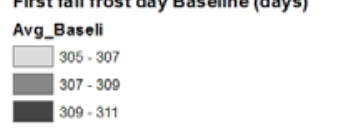

e) f)
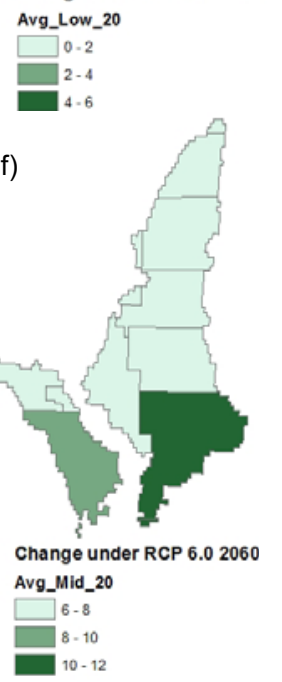

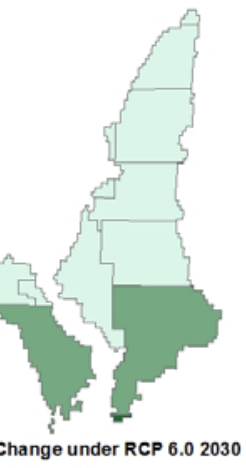

Avg_Mid203

$\square_{4-6}^{2-4}$

g)

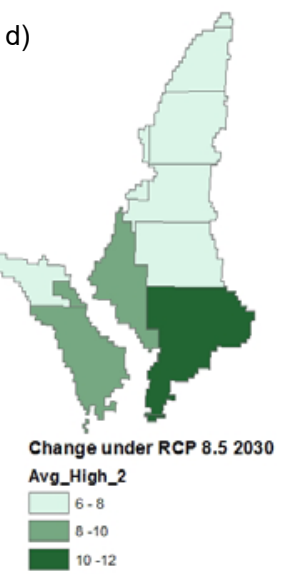

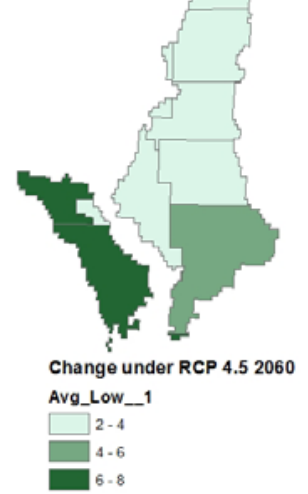

Fig. 12. First fall frost day in baseline period and spatial change under scenarios of climate change; $\mathrm{RCP}=$ representative concentration pathway; source: own study

a)

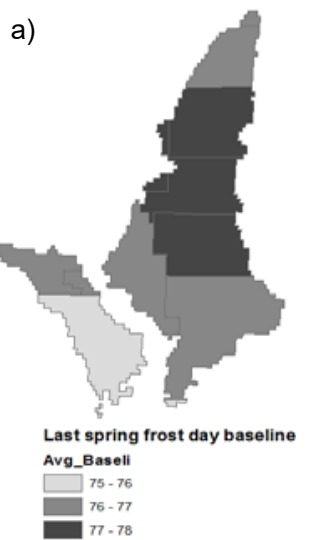

e)

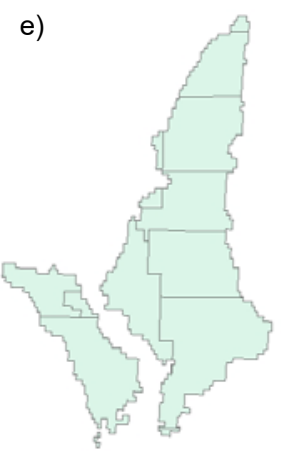

Avg_Low206 b)

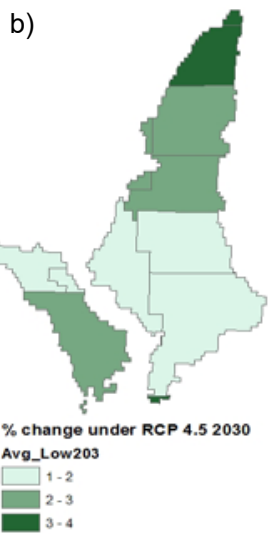

f)

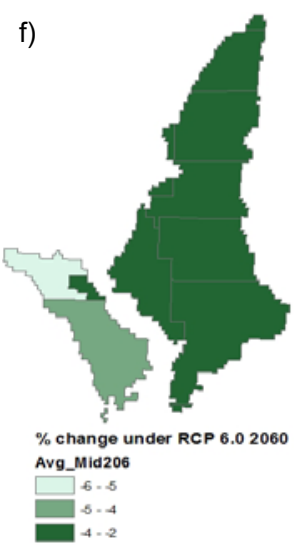

c)

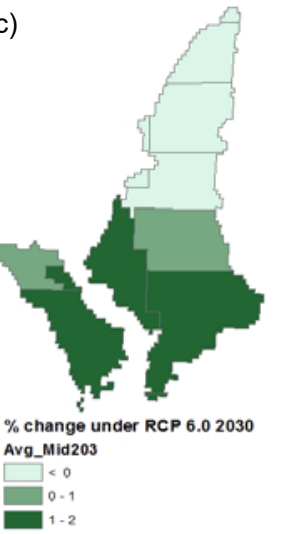

g)

Avg_High_1

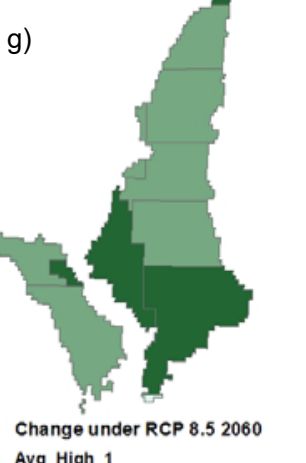

$14-17$
$17-20$ 


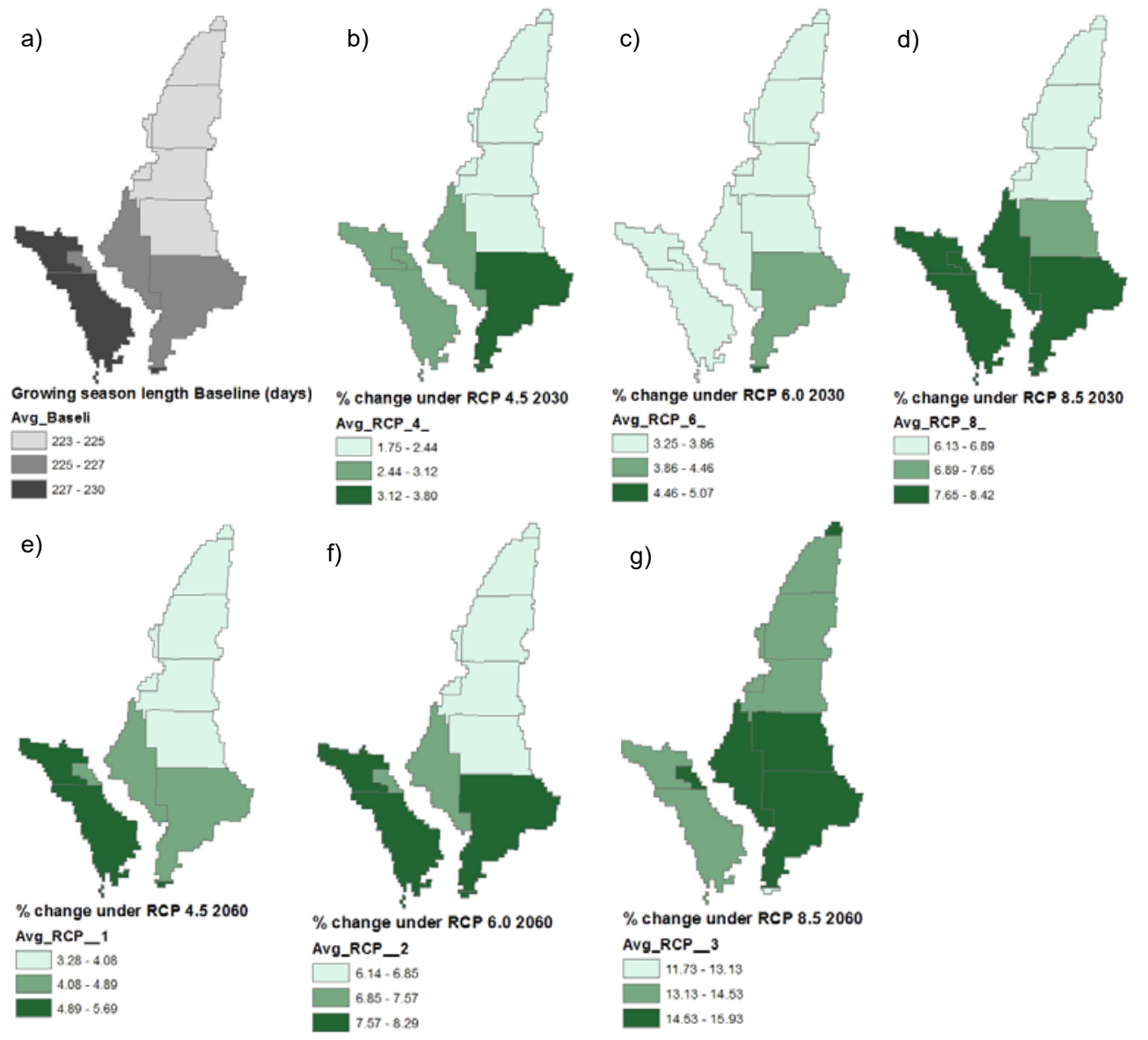

Fig. 14. Growing season length in baseline period and spatial change under scenarios of climate change; $\mathrm{RCP}=$ representative concentration pathway; source: own study

Spatial analysis reveals that the growing season length increases as you go northward (Fig. 14a). There are rises in growing season length under all scenarios of 2030, most of which are pronounced in the south of the study area (Fig. 13b, c, d). The 2060 scenarios are quite consistent with those in 2030, with increases being commensurate with severity of RCP projections (Fig. 14e, f, g). RCP 8.5 reveals the greatest increase in growing season length for the study area relative to baseline period (Fig. 13g).

Previous satellite and climatological studies agree that there are shifts in timing and length of the growing season [TUCKER et al. 2001]. Increasing growing season length provides opportunities for earlier planting, ensuring maturation and possibilities of multiple cropping in Arkansas. Our results project an increase in the length of the growing season but increased warmth during growing season may cause slight decreases in yields; because higher temperatures speed development and reduce time to accumulate dry matter [ACIA 2004; LINDERHOLM 2006; STOCKER et al. 2013a].

\section{ADAPTATION AND POLICY IMPLICATIONS}

Arkansas faces key challenges for water use which could be exacerbated by temperature increases, mainly because these effects will affect evapotranspi- ration and plant water use. Any adaptations will have to address increase in productivity verses, quantity, amount, timing and supply of water to the competing sectors of the economy in the face of climate change [WARD, Pulido-VelazQuez 2008]. Rice is the most water intensive crop in irrigated agriculture in Arkansas accounting for $\$ 1.2$ billion cash receipts. Studies reveal that, adaptation of multiple inlet irrigation approach could lead to increases in rice yields up to $3.4 \%$ due to water use efficiency [VORIES et al. 2005]. In the multiple inlet system, the operator can fill all paddies simultaneously; flood fields quicker, leading to reduced pumping times and increased irrigation efficiency [CHEN, LIU 2002; WATKINS et al. 2012].

Construction of reservoirs with tail water recovery has been shown to improve farm net returns by $15 \%$ and decreased aquifer depletion by $39 \%$. It also improved water quality, reduced pollutant loadings and enhanced conservation [KovACS et al. 2014]. Studies by KovACs et al. [2015] showed that technology adoption should be the main focus of conservation groups as opposed to advocacy of environmental values. Tax on ground water was more effective in increasing water table; subsidy for reservoir construction was cost effective but inefficient in maintain aquifer levels [KovACS et al. 2014; YounG et al. 2004].

Other strategies proposed include, cost sharing for efficient irrigation technologies, incentives for 
change of irrigated to dry land crop production, tradable quotas for groundwater stock and switching to less water intensive bioenergy crops [HAMMOURI et al. 2015]. More weight could be given to: site productivity maintenance, insect pest management, soil water conservation together with socio-economic values [DING, PETERSON 2012; Kovacs et al. 2014; WHEELER et al. 2012; ZHANG et al. 2007a] . Ultrashort season cultivars for cereals like corn; with maturity dates of 75 to 90 days is worth consideration. These could evade weather related problems affecting quality like Aflatoxin while giving consistent desirable yields [KEISLING et al. 1999]. As indicated by this study, farmers will likely plant longer season varieties. It is also interesting to hypothesize that, more wheat and cotton would be planted instead of soybean, corn and rice due to future water and temperature dynamics.

In Arkansas, an integrated approach will be key to policy formulations incorporating both hard infrastructures (reservoirs, efficient irrigation, bio system engineering for soil and water conservation, tail water recovery systems) and softer measures (insurance schemes, water buyouts, subsidies and taxes). These could also take the form of pure technological (infrastructure) or behavioural (altered ground water use). There is no fit answer for all situations and effectiveness of various options to fully reduce risks and vulnerabilities due to climate change is still unknown.

\section{CONCLUSIONS}

This study examined impact of climate change on irrigated agriculture in Arkansas through assessment of agro-meteorological indicators, including precipitation changes, frost days, growing season length and growing degree days. Results show almost negligible increases in total precipitation. There is negligible rise in percent number of days with extreme precipitation. Analysis of extreme rainfall events carried out for all periods (baseline, 2030 and 2060) have shown a shift towards more intense precipitation which accounts for $2.2 \%$ rise in extreme precipitation in 2060. Farmers will have to invest more in crop insurance to offset the risks of extreme weather.

Frost days per year have been decreasing in the baseline period and are still projected to decrease thereby reducing frost risks to crops. Under RCP 8.5, the last frost day is projected to come at least two weeks earlier in 2060. This could be a positive as it allows for stable prediction of planting season. Results show an increasing trend of delayed first frost period. Ideally, farmers should be able to plant long season cultivars, sow earlier in addition to having a greater variety of other crops. The association of frost days with growing season is very strong confirming that temperature is a key factor of influence. Results reveal lengthening of growing season under all scenarios of climate change for 2030 and 2060. By 2030 , the growing season is projected to increase by
10 days on average; while for 2060 there would be an increase of about 19 days.

Growing degree days are projected to rise for all crops studied under all scenarios of climate change with cotton showing an increase of up to $37 \%$. It is anticipated that these changes in GDDs for crops will interact with other crop limiting factors such as temperature, precipitation, diseases and weeds to affect crop productivity. These results indicate that farmers will have to plant the right crop varieties at the right time. They will also have to weigh the planting decisions against inherent risks such as frostbite and diseases. Excessive precipitation might lead to delayed harvest in summer crops because of wet soils; which also delays planting season. In the future, climate forecasts will be a key determinant factor of planting dates and variety selection for farmers.

Arkansas agriculture will face key water challenges in future, which will be exacerbated by temperature increases due to climate change. Adaptations will have to address quantity, timing and supply of water to competing sectors of the economy. Rice remains the likely casualty of water challenges in the future. Construction of reservoirs with tail water recovery, tax on ground water, tradable quotas, ultrashort season cultivars, soil and water conservation are among remedies for adaptation open to policy makers. Most importantly, incorporation of both hard infrastructures (bio system engineering for soil and water conservation, efficient irrigation systems) and softer measures (subsidies and taxes, insurance schemes) will form an effective integrated approach to policy formulation. These approaches could be both technological (infrastructure) and behavioural (altered ground use).

\section{REFERENCES}

ACIA 2004. Impacts of a warming Arctic - Arctic climate impact assessment. ACIA overview report. Cambridge, UK. Cambridge University Press. ISBN 0521617782 pp. 140.

Alexander L., Zhang X., Peterson T., Caesar J., Gleason B., Klein TanK A., Haylock M., Collins D., TRewin B., Rahimzadeh F. 2006. Global observed changes in daily climate extremes of temperature and precipitation. Journal of Geophysical Research: Atmospheres. Vol. 111. Iss. D5 p. 1-22. DOI 10.1029/2005JD 006290/full

Bernacchi C.J., Leakey A.D., Heady L.E., Morgan P.B., DOHLEMAN F.G., MCGRATH J.M., GILleSPIE K.M., Wittig V.E., Rogers A., Long S.P. 2006. Hourly and seasonal variation in photosynthesis and stomatal conductance of soybean grown at future $\mathrm{CO}_{2}$ and ozone concentrations for 3 years under fully open-air field conditions. Plant, Cell \& Environment. Vol. 29. Iss. 11 p. 2077-2090.

Blanc E., Strzepek K., Schlosser C.A., Jacoby H.D., Gueneau A., Fant C., Rausch S., Reilly J.M. 2013. Analysis of US water resources under climate change. MIT Joint Program on the Science and Policy of Global Change. Report. No. 239. Cambridge, MA pp. 43. 
CHEN S.-K., LIU C.W. 2002. Analysis of water movement in paddy rice fields (I) experimental studies. Journal of Hydrology. Vol. 260. Iss. 1-4 p. 206-215.

CZARNECKI J.B., SCHRADER T.P. 2013. Effects of recent climate variability on groundwater levels in eastern Arkansas. Scientific Investigations Report 2012-5258. Reston, VA. USGS pp. 17.

Ding Y., Peterson J.M. 2012. Comparing the cost-effectiveness of water conservation policies in a depleting aquifer: A dynamic analysis of the Kansas High Plains. Journal of Agricultural and Applied Economics. Vol. 44. Iss. 2 p. 223-234.

DraKe B.G., Gonzãlez-Meler M.A., Long S.P. 1997. More efficient plants: A consequence of rising atmospheric $\mathrm{CO}_{2}$ ? Annual Review of Plant Biology. Vol. 48 p. 609-639.

EASTERLING D.R. 2002. Recent changes in frost days and the frost-free season in the United States. Bulletin of the American Meteorological Society. No. 83 p. 13271332.

Elliott J., Deryng D., Muller C., Frieler K., KonZMANn M., Gerten D., Glotter M., Florke M., WadA Y., Best N., Eisner S., FeKete B.M., Folberth Ch., Foster I., Gosling S.N., Haddeland I., Khabarov N., Ludwig F., Masaki Y., Olin S., Rosenzweig C., RuAne A.C., Satoh Y., Schmid E., Stacke T., Tang Q., WISSER D. 2014. Constraints and potentials of future irrigation water availability on agricultural production under climate change. Proceedings of the National Academy of Sciences. No. 111 p. 3239-3244.

ESRI 2000. ArcGIS, Environmental Systems Research Institute. Redlands, California. ESRI Press.

FEnG S., Hu Q. 2004. Changes in agro-meteorological indicators in the contiguous United States: 1951-2000. Theoretical and Applied Climatology. Vol. 78. Iss. 4 p. 247-264.

Feng S., Hu Q., Huang W., Ho C.-H., Li R., TANG Z. 2014. Projected climate regime shift under future global warming from multi-model, multi-scenario CMIP5 simulations. Global and Planetary Change. Vol. 112 p. 4152. DOI 10.1016/j.gloplacha.2013.11.002.

GiLliP J.A., CZARNECKI J.B. 2009. Validation of a groundwater flow model of the Mississippi River Valley alluvial aquifer using water-level and water-use data for 1998-2005 and evaluation of water-use scenarios. Scientific Investigations Report. Reston, VA. US GS pp. 23.

Griggs D.J., Noguer M. 2002. Climate change 2001: The scientific basis. Contribution of working group I to the third assessment report of the intergovernmental panel on climate change. Weather. Vol. 57 p. 267-269.

Hammouri N., Al-QinNa M., Salahat M., AdAmowski J., PRASHER S.O. 2015. Community based adaptation options for climate change impacts on water resources: The case of Jordan. Journal of Water and Land Development. No 26 p. 3-17.

Hassan Q.K., Bourque C.P., Meng F.-R., Richards W. 2007. Spatial mapping of growing degree days: an application of MODIS-based surface temperatures and enhanced vegetation index. Journal of Applied Remote Sensing. Vol. 1, 013511 pp. 12.

Hatfield J.L., Boote K.J., Kimball B., Ziska L., IZaurRALDE R.C., ORT D., ThOMSON A.M., Wolfe D. 2011. Climate impacts on agriculture: implications for crop production. Agronomy Journal. Vol. 103 p. 351-370.
Holland T.W. 2007. Water use in Arkansas, 2005. Scientific Investigations Report 2007-5241. Reston, VA. USGS pp. 32.

Howell T., EveTt S., Tolk J., SCHNEIDER A. 2004. Evapotranspiration of full-, deficit-irrigated, and dryland cotton on the Northern Texas High Plains. Journal of Irrigation and Drainage Engineering. Vol. 130 p. 277-285.

Ingram K.T., Dow K., CARTER L., ANDERSON J. (ed.) 2013. Climate of the Southeast United States: Variability, change, impacts, and vulnerability. Island Press. ISBN 978-1-61091-509-0 pp. 341.

Karl T.R., Melillo J.M. 2009. Global climate change impacts in the United States. New York. Cambridge University Press. ISBN 978-0-521-14407-0 pp. 188.

Keisling T.C., MAsCagni Jr, H.J., Cox A.D., Gordon E.C. 1999. Evaluation of the adaptation of ultra-short season corn for the mid-south. In: Proceeding of $22^{\text {nd }}$ Annual Southern Conservation and Tillage Conference for Sustainable Agriculture. Georgia Agricultural Experiment Stations Special Publication. No. 95. Tifton, GA p. 6-8.

Kovacs K., Popp M., Brye K., West G. 2015. On-farm reservoir adoption in the presence of spatially explicit groundwater use and recharge. Journal of Agricultural and Resource Economics. Vol. 40(1) p. 23-49.

Kovacs K., Wailes E., West G., Popp J., Bektemirov K. 2014. Optimal spatial-dynamic management of groundwater conservation and surface water quality with on-farm reservoirs. Journal of Agricultural and Applied Economics. Vol. 46(4) p. 409-437.

Kunkel K.E., ANDSAger K., EAsterling D.R. 1999. Long-term trends in extreme precipitation events over the conterminous United States and Canada. Journal of Climate. Vol. 12 p. 2515-2527.

Leakey A.D., Xu F., Gillespie K.M., McGrath J.M., Ainsworth E.A., ORT D.R. 2009. Genomic basis for stimulated respiration by plants growing under elevated carbon dioxide. Proceedings of the National Academy of Sciences. Vol. 106(9) p. 3597-3602.

LINDERHOLM H.W. 2006. Growing season changes in the last century. Agricultural and Forest Meteorology. Vol. 137. Iss. $1-2$ p. $1-14$.

Lobell D.B., Field C.B. 2007. Global scale climate crop yield relationships and the impacts of recent warming. Environmental Research Letters. Vol. 2. No. 1 p. 1-7. DOI 10.1088/1748-9326/2/1/014002.

LOKA D., OOSTERHUIS D. 2010. Effect of high night temperatures on cotton respiration, ATP levels and carbohydrate content. Environmental and Experimental Botany. Vol. 68 p. 258-263.

McMaster G.S., Wilhelm W. 1997. Growing degreedays: One equation, two interpretations. Agricultural and Forest Meteorology. Vol. 87. Iss. 4 p. 291-300.

Melillo J.M., Richmond T., Yohe G.W. (eds.) 2014. Climate change impacts in the United States: The third national climate assessment. U.S. Global Change Research Program. No. 841. DOI 10.7930/J0Z31WJ2.

Mereu V., Gallo A., Carboni G., Spano D. 2012. April. Impact of climate change and adaptation strategies on crop production in Nigeria. In: EGU General Assembly Conference Abstracts. Vol. 14 p. 13094.

Miller P., Lanier W., Brandt S. 2001. Using growing degree days to predict plant stages. MT200103 AG. No. 7. MSU Extension Service pp. 7.

Mitra J. 2001. Genetics and genetic improvement of drought resistance in crop plants. Current Science. Vol. 80 p. $758-763$. 
Moonen A., Ercoli L., Mariotti M., Masoni A. 2002. Climate change in Italy indicated by agrometeorological indices over 122 years. Agricultural and Forest Meteorology. Vol. 111 p. 13-27.

MORISON J., GIFFORD R. 1984. Plant growth and water use with limited water supply in high $\mathrm{CO}_{2}$ concentrations. I. Leaf area, water use and transpiration. Functional Plant Biology. Vol. 11 p. 361-374.

NASS, USDA 1997. Usual planting and harvesting dates for US field crops [online]. Agricultural Handbook. No. 628. National Agricultural Statistics Service, United States Department of Agriculture pp. 51. [Access 15.04.2017]. Available at: https://usda.mannlib.cornell. edu/usda/nass/planting/uph97.pdf

Nickerson C., Ebel R., Borchers A., Carriazo F. 2011. Major uses of land in the United States, 2007. Economic Information Bulletint. No. 89. US Department of Agriculture, Economic Research Service pp. 57.

Pathak H., Ladha J., Aggarwal P., Peng S., Das S., Singh Y., Singh B., Kamra S., Mishra B., Sastri A. 2003. Trends of climatic potential and on-farm yields of rice and wheat in the Indo-Gangetic Plains. Field Crops Research. Vol. 80 p. 223-234.

Pingale S., AdAmowski J., Jat M., Khare D. 2015. Implications of spatial scale on climate change assessments. Journal of Water and Land Development. No. 26 p. $37-$ 55.

Porter J.R., GAWITH M. 1999. Temperatures and the growth and development of wheat: A review. European Journal of Agronomy. Vol. 10 p. 23-36.

Rosegrant M.W., Ringler C., Zhu T. 2009. Water for agriculture: Maintaining food security under growing scarcity. Annual Review of Environment and Resources. Vol. 34 p. 205-222.

Sarma A., Kumar T.L., Koteswararao K. 2008. Development of an agroclimatic model for the estimation of rice yield. Journal of Indian Geophysical Union. Vol. 12 p. 89-96.

SATAKE T., HAYASE H. 1970. Male sterility caused by cooling treatment at the young micro-spore stage in rice plants. 5. Estimations of pollen developmental stage and the most sensitive stage to coolness. Nihon Sakumotsugaku Kai Kiji. Proceedings of the Crop Science Society of Japan. Vol. 39. No. 4 p. 468-473.

SCHAIBle G., Aillery M. 2012. Water conservation in irrigated agriculture: Trends and challenges in the face of emerging demands. Economic Information Bulletin. No. 99. US Department of Agriculture, Economic Research Service pp. 60.

Schewe J., Heinke J., Gerten D., Haddeland I., Arnell N.W., Clark D.B., Dankers R., Eisner S., Fekete B.M., Colon-Gonzalez F.J., Gosling S.N., Kim H., Liu X., Masaki Y., Portmann F.T., Satoh Y., Stacke T., Tang Q., Wada Y., Wisser D., Albrecht T., FrielER K., Piontek F., Warszawski L., Kabat P. 2014. Multimodel assessment of water scarcity under climate change. Proceedings of the National Academy of Sciences. Vol. 111 p. 3245-3250.

SCHLenKer W., Hanemann W.M., Fisher A.C. 2005. Will US agriculture really benefit from global warming? Accounting for irrigation in the hedonic approach. American Economic Review. Vol. 95. No. 1 p. 395-406.

SChlenKer, W., HanemanN W.M., Fisher A.C. 2007. Water availability, degree days, and the potential impact of climate change on irrigated agriculture in California. Climatic Change. Vol. 81. Iss. 1 p. 19-38.
SCHLENKER W., ROBERTS M.J. 2009. Nonlinear temperature effects indicate severe damages to US crop yields under climate change. Proceedings of the National Academy of Sciences. Vol. 106 p. 15594-15598.

SHEFFIELD J., GoteTi G., WoOd E.F. 2006. Development of a 50-yr high-resolution global dataset of meteorological forcings for land surface modelling. Journal of Climate. Vol. 19 (13) p. 3088-3111.

Snider J.L., Oosterhuis D.M., Collins G.D., Pilon C., FitzSimons T.R. 2013. Field-acclimated Gossypium hirsutum cultivars exhibit genotypic and seasonal differences in photosystem II thermostability. Journal of Plant Physiology. Vol. 170. Iss. 5 p. 489-496.

SNOWden C., Ritchie G., CAVE J., KeEling W., Rajan N. 2013. Multiple irrigation levels affect boll distribution, yield, and fiber micronaire in cotton. Agronomy Journal. Vol. 105 p. 1536-1544.

Stocker T., Qin D., Plattner G., Tignor M., Allen S., Boschung J. 2013a. IPCC, 2013: Summary for Policymakers in Climate Change 2013: The Physical Science Basis, Contribution of Working Group I to the Fifth Assessment Report of the Intergovernmental Panel on Climate Change pp. 1535.

Stocker T., Qin D., Plattner G., Tignor M., Allen S., Boschung J., Nauels A., Xia Y., BeX B., Midgley B. 2013b. IPCC, 2013: Climate change 2013: The physical science basis. Contribution of working group I to the fifth assessment report of the intergovernmental panel on climate change. Cambridge, UK, New York, NY, USA. Cambridge University Press pp. 27.

Tucker C.J., Slayback D.A., Pinzon J.E., Los S.O., MYNENI R.B., TAYLOR M.G. 2001. Higher northern latitude normalized difference vegetation index and growing season trends from 1982 to 1999 . International Journal of Biometeorology. Vol. 45 p. 184-190.

Vories E., TACKer P., HogAn R. 2005. Multiple inlet approach to reduce water requirements for rice production. Applied Engineering in Agriculture. Vol. 21 p. 611616.

Ward F.A., Pulido-VelazQuez M. 2008. Water conservation in irrigation can increase water use. Proceedings of the National Academy of Sciences. Vol. 105 p. 1821518220.

Walthall C., Hatfield J., Backlund P., Lengnick L., Marshall E., Walsh M., Adkins S., Aillery M., Ainsworth E., Ammann C., Anderson C.J., Bartomeus I., Baumgard L.H., Booker F., Bradley B., Blumenthal D.M., Bunce J., Burkey K., Dabney S.M., Delgado J.A., Dukes J., FunK A., Garrett K., Glenn M., Grantz D.A., GoOdrich D., Hu S., IzaurRALDE R.C., JONES R.A.C., KIM S-H., LEAKY A.D.B., Lewers K., Mader T.L., McClung A., Morgan J., Muth D.J., Nearing M., OOSTerhuis D.M., ORT D., Parmesan C., Pettigrew W.T., Polley W., Rader R., Rice C., Rivington M., Rosskopf, Salas W.A., SolLenberger L.E., SRygley R., Stöckle C., TAKle E.S., Timlin D., White J.W., Winfree R., Wright-Morton L., ZISKA L.H. 2012. Climate change and agriculture in the United States: Effects and adaptation. USDA Technical Bulletin 1935. Washington, DC pp. 186.

WATKINS K.B. 2012. The 2010 and 2011 Arkansas drought experience. Choices. No. 27(3) p. 1-7.

Wheeler E., Golden B., Johnson J., Peterson J.M. 2012. Economic efficiency of short-term versus long-term water rights buyouts. Journal of Agricultural and Applied Economics. Vol. 40. Iss. 2 p. 493-501. 
Young K.B., Wailes E.J., Pop J.H., SMARTT J. 2004. Value of water conservation improvements on Arkansas rice farms. Journal of the ASFMRA. Vol. 67 p. 119-126.

Zhang W., Ricketts T.H., KREMEN C., CARNEy K., SwinTON S.M. 2007a. Ecosystem services and dis-services to agriculture. Ecological Economics. Vol. 64 p. 253-260.
Zhang X., Zwiers F.W., Hegerl G.C., Lambert F.H., Gillett N.P., Solomon S., Stott P.A., Nozawa T. 2007. Detection of human influence on twentiethcentury precipitation trends. Nature. Vol. 448 p. 461465 .

\section{John W. MAGUGU, Song FENG, Qiuqiong HUANG, Yongjun ZHANG, Grant H. WEST}

\section{Analiza scenariuszy klimatycznych i ich wpływ na rolnictwo we wschodniej części Arkansas}

\section{STRESZCZENIE}

Wpływ zmian klimatu na wzrost upraw jest dynamiczny i trudny do ilościowej oceny z powodu różnorodności powiązanych efektów i ich interakcji w całym systemie Ziemi. Głównym celem badań prezentowanych w niniejszej pracy było ustalenie, jak zmiany klimatu w przyszłości mogą wpłynąć na rolnictwo, na podstawie oceny parametrów związanych z temperaturą i opadami. Analizowano następujące parametry: udział (w \%) dni deszczowych z ekstremalnym opadem, udział ekstremalnych opadów w stosunku do opadów ogółem, pierwsze jesienne dni z mrozem, ostatnie wiosenne dni z mrozem, stopniodni w sezonie wegetacyjnym, długość sezonu wegetacyjnego, i sumę opadów. Wyniki wykazują umiarkowany wzrost całkowitych opadów i niewielki wzrost opadów ekstremalnych - do 2,2\% do roku 2060 wg scenariusza Representative Concentration Pathway (RCP 8.5). W 2060 roku pierwsze jesienne dni z mrozem wystąpią później, ostatnie wiosenne dni z mrozem wystąpią wcześniej, a sezon wegetacyjny wydłuży się o ok. 2 tygodnie. Zgodnie ze wszystkimi scenariuszami przewiduje się, że liczba stopniodni w sezonie wegetacyjnym zwiększy się dla wszystkich upraw, a największy przyrost (maksymalnie o 37\%) w stosunku do okresu bazowego prognozuje się dla upraw bawełny.

Slowa kluczowe: opady, rolnictwo, scenariusze klimatyczne, temperatura, zmiany klimatu 